\title{
ANALISIS YURIDIS TERHADAP MOGOK KERJA SEBAGAI ALASAN PEMUTUSAN HUBUNGAN KERJA (STUDI KASUS: PUTUSAN NOMOR 67 PK/PDT.SUS-PHI/2018)
}

\author{
Naomi Artha Nauli Arman \\ (Mahasiswa Program S1 Fakultas Hukum Universitas Tarumanagara) \\ (E-mail: naomiarman63@yahoo.co.id)
}

Dr. Andari Yurikosari, S.H., M.H.

(Corresponding Author)

(Dosen Fakultas Hukum Universitas Tarumanagara. Meraih Sarjana Hukum pada Fakultas Hukum Universitas Indonesia, Magister Hukum pada Fakultas Hukum Universitas Indonesia, Doktor (Dr.) pada Fakultas Hukum Universitas Indonesia)

(E-mail: andari_yurikosari@gmail.com)

\begin{abstract}
A strike is a basic or normative right attached to workers so it needs to be protected. The meaning of strike is regulated in Law Number 13/2003 concerning Manpower Article 1 Paragraph (23), illegal strike is regulated in Decree of the Minister of Manpower and Transmigration Number KEPMEN232/200. Regarding the Legal Effects of a Strike Invalid. Lately there have been cases of employers terminating employment with workers who are on strike. The main problem here is how the judicial analysis of the judge's decision on termination of employment by reason of a legal strike and how legal protection for workers who are terminated due to strikes at PT. Sanfu Indonesia. Conducting research methods in a normative, prescriptive manner, conducting research using primary and secondary data in the form of interviews and in the form of books or literature. With the conclusion, in accordance with the provisions of Law Number 13/2003 Concerning Labor Strikes conducted by workers is legal because workers have carried out strike procedures that are not in conflict with KEPMEN Number 232/2003 Concerning the Legal Results of Non-Strikes Legitimate. In terms of protection, the worker I laborer has received protection because the worker has obtained his right in the form of severance pay, and also because the worker is carrying out a legal strike, so that it is protected by Law No. 13 of 2003 concerning Labor Article 153.
\end{abstract}

Keywords: Termination of employment, legal strike, legal protection

\section{PENDAHULUAN}

\section{A. LatarBelakang}

Mogok kerja adalah hak dasar atau suatu hak normatif yang melekat pada pekerja/buruh yang harus dilindungi. Sebab mogok kerja merupakan senjata yang ampuh bagi pekerja dalam memperjuangkan aspirasinya. 
Mogok kerja diatur dalam UU No. 13/2003 tentang Ketenagakerjaan. Mogok kerja itu terbagi dalam dua kriteria, yaitu mogok kerja sah dan mogok kerja tidak sah. Walaupun mogok kerja merupakan hak normatif oleh pekerja/buruh tetapi tetap ada pengaturannya, mogok kerja sah terdapat dalam UU No 13/2003 Tentang Ketenagakerjaan, sedangkan mogok kerja tidak sah terdapat dalam KEPMEN 232/2003 tentang Akibat Hukum Mogok Kerja yang Tidak Sah.. Ada beberapa alasan tentang mogok kerja tidak sah yaitu terdapat pada pasal 3, yang menyebutkan bahwa:

a. bukan karena gagal perundingan;

b. tanpa pemberitahuan kepada pengusaha;

c. pemberitahuan kurang dari tujuh hari sebelum melakukan mogok ;

d. isi pemberitahuan tidak sesuai dengan ketentuan Pasal 140 ayat (2) huruf a, b, c, dan d Undang-undang Nomor 13 Tahun 2003 tentang Ketenagakerjaan.

Mogok kerja juga dianggap tidak sah apabila masalah mogok kerja bukan karena gagal perundingan dan tidak adanya pemberitahuan. Maksud gagal perundingan adalah tidak tercapainya kesepakatan dalam penyelesaian perselisihan antara pekerja/buruh yang dapat disebabkan karena pengusaha tidak mau melakukan perundingan

Akhir - akhir ini banyak kasus dimana para pengusaha melakukan PHK terhadap karyawannya yang melakukan aksi mogok kerja. Salah satu kasus pelanggaran Undang-Undang dan hak pekerja yang membuat Penulis melakukan penelitian ini karena adanya (PHK) berdasarkan Putusan Nomor 67 PK/Pdt.Sus-PHI/2018 dikarenakan aksi mogok kerja yang dilakukan oleh karyawan PT. SAN FU INDONESIA. Mereka melakukan aksi mogok kerja yang sah dengan alasan ingin menjadi pegawai tetap, dimana mereka saat ini masih menjadi pegawai tidak tetap. Tapi dalam putusan tersebut mogok kerja yang sah itu diputus oleh hakim putus hubungan kerja antara karyawan 
dengan pengusaha. Berdasarkan keterangan diatas, penulis ingin untuk mengkaji analisi yuridis mengenai putusan hakim terhadap mogok kerja yang dilakukan oleh karyawan PT. Sanfu Indonesia dan bagaimana perlindungan yang dapat diterima karyawan PT SAN FU Indonesia, penelitian tersebut akan dituangkan dalam praproposal yang berjudul "Mogok Kerja Sebagai Alasan Pemutus Hubungan Kerja “

B. Perumusan Masalah

1. Analisis Yuridis Putusan Hakim Terhadap Pemutusan Hubungan Kerja Dengan alasan Mogok kerja Sah (Putusan Nomor 67 PK/Pdt.Sus-PHI/2018)

2. Bagaimana perlindungan hukum bagi tenaga kerja yang di Putus Hubungan Kerjanya karena aksi mogok kerja pada PT. Sanfu Indonesia (Putusan Nomor 67 PK/Pdt.Sus-PHI/2018).

C. Metode Penulisan

Menurut Soerjono Soekanto, penelitian hukum merupakan suatu bentuk kegiatan ilmiah, yang didasarkan pada metode, sistematika, dan pemikiran tertentu, yang bertujuan untuk mempelejari suatu atau beberapa gejala hukum tertentu, dengan jalan menganalisisnya ${ }^{1}$

1. Jenis Penelitian

Metode penelitian ini adalah penelitian normatif, yaitu penelitian terhadap bahan pustaka yang merupakan data dasar yang dalam ilmu pengetahuan digolongkan sebagai data sekunder ${ }^{2}$

2. Sifat Penelitian

\footnotetext{
${ }^{1}$ Sorjono Soekanto, Pengantar Penelitian Hukum, (Jakarta: UI Press, 1981) hal. 43.

2 Soerjono Soakanto dan Sri Mamudji, Penelitian Hukum Normatif, (Jakarta: Raja GrafindoPersada, 2004), hal. 24
} 
Sifat penelitian yang digunakan dalam penelitian ini adalah bersifat preskriptif yaitu penelitan yang dimaksudkan untuk memberikan pendapat atas hasil penelitian

3. Jenis Data

Penelitian dalam mengumpulkan data dan fakta-fakta, peneliti menggunakan jenis data primer dan sekunder.

a) Data Hukum Primer:

1. UU Nomor $13 / 2003$ tentang Ketenagakerjaan

2. KEPMEN 232/2003 tentang Akibat Hukum Mogok Kerja Yang tidak sah

b) Data Hukum Sekunder, terdiri atas buku atau jurnal hukum, pandangan para ahli hukum (doktrin) berupa buku-buku yang menunjang topik penelitian yaitu mengenai ketenagakerjaan atau perburuhan, mogok kerja, dan mengenai Pemutusan Hubungan Kerja (PHK)

c) Bahan Hukum Tersier, bahan penelitian yang terdiri atas buku bukan hukum yang berkaitan dengan penelitian.

4. Teknik Pengumpulan Data

Penelitian ini alat pengumpulan data yang dipergunakan ialah study kasus (study case).

5. Teknik Analisis Data

Teknik yang penulis gunakan dalam analisis data adalah dengan menggunakan metode analisi Normatif Kualitatif yaitu suatu metode yang berusaha untuk memaparkan data disertai dengan analisa yang mendalam.

\section{PEMBAHASAN}

\section{A. Analisis Yuridis Mengenai Putusan Hakim Terhadap Pemutusan Hubungan Kerja dengan Alasan Mogok kerja}


Pihak pemberi kerja dalam kasus ini adalah PT. Sanfu Indonesia yang melakukan PHK kepada 12 karyawannya berlasan bahwa pekerja tersebut telah melakukan mogok aksi kerja selama 5 hari berturut-turut sehingga dapat dikatakan sebagai mangkir. Pada dasarnya mogok kerja diperbolehkan oleh UU Nomor 13/2003, namun mogok kerja tanpa alasan yang sah menurut Pasal 6 Kepmenketrans No. 232/2003 tentang Akibat Hukum Mogok Kerja yang Tidak Sah; dapat menyebabkan pengusaha melakukan (PHK) kepada pekerja dengan alasan mangkir, (PHK) dengan alasan mangkir tidak memerlukan perundingan bipatrit dan penetapan pengadilan hubungan industrial.

Pada Kasus (PHK) pada pekerja di PT. Sanfu Indonesia, pekerja melakukan aksi demo mogok kerja. Pasal 137 UU RI Nomor 13/2003 tentang Ketenagakerjaan disebutkan bahwa mogok kerja merupakan hak dasar buruh hak pekerja dan serikat pekerja yang dilakukan secara sah, tertib, damai sebagai akibat gagalnya perundingan. Mogok kerja yang dilakukan oleh pekerja/buruh adalah mogok kerja yang sah, karena tidak bertentangan dengan KEPMEN Nomor 232/2003 Tentang Akibat Hukum Mogok Kerja Yang Tidak Sah pasal 3 yang menyebutkan bahwa mogok kerja bukan karena perundingan, mogok kerja tanpa pemberitahuan kepada pengusaha/ instansi yang berwenang, tanpa pemberitahuan kurang dari tujuh hari sebelum melakukan mogok. Pada kasus mogok kerja oleh pekerja melakukan pemberitahuan dahulu yaitu dengan pihak Disnakersostrans, Management Perusahaan PT. Sanfu Indonesia dan Kepolisian polres Kab. Purwakarta dengan di tembuskan ke instansi yang berwenang, hal ini sesuai Pasal 140 Ayat (2) UU RI Nomor 13/2003 tentang Ketenagakerjaan. Mereka melakukan mogok kerja tersebut untuk memperjuangkan pekerja-pekerja lainnya di perusahaan penggugat yang merupakan Anggota PPA PPMI yang selama ini statusnya harian dan kontrak untuk diangkat menjadi karyawan tetap (PKWTT). Mogok kerja itu dilakukan karena akibat gagalnya perundingan dengan pengusaha, padahal perundingan tersebut sudah diminta 3 (tiga) kali 
oleh pekerja/buruh, perundingan itu tidak hanya dalam proses bipartrit tetapi juga dalam dalam hal proses mediasi. Akan tetapi dalam proses perundingan mediasi pengusaha hanya menghadiri satu (1) kali perundingan, di mana pekerja/buruh meminta pihak pengusaha untuk menghadiri mediasi sebanyak tiga (3) kali. Pekerja/buruh melakukan aksi mogok tersebut sebagai bentuk kekecewaannya akan gagalnya perundingan yang telah dilakukan dengan pengusaha

Pasal 168 Ayat (1) Undang-Undang Nomor 13 Tahun 2003 Tentang Ketenagakerjaan menyebutkan bahwa pekerja/buruh yang mangkir selama lima hari kerja atau lebih berturut-turut tanpa keterangan yang dilengkapi dengan bukti yang sah dan telah dipanggil oleh pengusaha dua kali secara patut dan tertulis, dapat diPHK karena dikualifikasikan sebagai mengundurkan diri. Berkaitan dengan hal ini ternyata pengusaha tidak melakukan pemanggilan untuk bekerja kembali yang sebagaimana dimaksud dalam ketentuan Pasal 6 KEPMEN 232/2003. Pengusaha tidak melakukan pemanggilan untuk bekerja kembali kepada pekerja, sehingga tidak sesuai dengan Pasal 168 UU RI Nomor 13/2003 tentang Ketenagakerjaan.

Berdasarkan alasan pengusaha tidak melakukan pemanggilan kembali sesuai dengan Pasal UU 13/2003 Tentang Ketenagakerjaan, dalam pertimbangan Judex Juris pada Putusan Peninjauan kembali disebutkan bahwa alasan mogok tidak sah dan pekerja tidak dapat membuktikan adanya perundingan yang gagal sebelumnya. Pada faktanya ternyata ada usaha perundingan bipartrit dan mediasi tetapi tidak tercapai oleh karenanya mogok titu adalah sah.

Mogok kerja sah karena pekerja/buruh sudah melakukan semua prosedur yang sesuai dengan ketentuan UU 13/2003 tentang Ketenagakerjaan, dan tidak bertentangan dengan Pasal 3 KEPMEN Nomor 232/2003 tentang Akibat Hukum Mogok Kerja Yang Tidak Sah, pada hal ini mogok kerja tersebut bukan karena atas kesalahan pekerja. Hakim dalam putusan No 67 
PK/Pdt.Sus-PHI/2018 memutuskan pekerja/buruh mendapatkan dua kali uang pesangon di mana ketentuan itu yang sesuai dengan Pasal 156 Ayat (2) UU 13/2003 Tentang Ketenagakerjaan dan juga hubungan kerja antara Pengusaha (tergugat rekonvensi) dan Pekerja/buruh (penggugat rekonvensi) putus. Putusan hakim pada Putusan Nomor 67PK/Pdt.Sus-PHI/2018 tentang melakukan Pemutusan Hubungan Kerja kepada pekerja/buruh, bukan karena alasan pekerja/buruh melakukan mogok kerja yang tidak sah, namun didasarkan pada alasan karena alasan disharmonisasi antara pekerja/buruh dengan pengusaha di mana hubungan ini tidak dapat dipertahankan lagi.

Pada Putusan Hakim No 67PK/Pdt/Sus-PHI/2018 menyatakan bahwa mogok yang dilakukan pekerja/buruh tersebut sudah sah, karena adanya bukti, yaitu Bukti. T dk/ p dRK -5: Surat No. 093/PPA PPMI SFI /2014 Tertanggal 17 November 2014 Perihal Pemberitahuan Aksi Mogok Kerja kepada pihak Disnakersostrans, Management Perusahaan PT. Sanfu Indonesia dan Kepolisian Polres Kabupaten Puwakarta dengan ditembuskan ke instansi yang berwenang Terkait Pemberitahuan Aksi Mogok Kerja yang akan dilakukan Tergugat dalam Konvensi / Para Penggugat dalam Rekonvensi. Dan juga bukti Bukti. T dk/ p dRK -6: Surat Nomor 099/PPA PPMI SFI/2014 tertanggal 03 Desember 2014 Perihal Surat Pengakhiran Aksi Mogok Kerja yang ditunjukan kepada pihak Dinaskersostrans, Management Perusahaan PT. Sanfu Indonesia dan Kepolisian Polres Kab. Puwakarta serta instansi yang berwenang terkait pengakhiran Mogok Kerja yang telah dilakukan oleh Tergugat Konvensi/ Penggugat rekonvensi.

Berdasarkan bukti pekerja/buruh sudah melakukan semua prosedur, dan tidak bertentangan dengan Pasal 3 KEPMEN No. 232/2003 tentang Akibat Hukum Mogok Kerja Yang Tidak Sah yang menyebutkan bahwa mogok kerja bukan akibat gagal perundingan, mogok kerja tanpa pemberitahuan kepada pengusaha, tanpa pemberitahuan kurang dari tujuh hari sebelum mogok kerja. Kasus mogok kerja dilakukan pekerja/buruh dengan 
melakukan pemberitahuan terlebih dahulu yaitu dengan pihak Disnakersostrans, Management Perusahaan PT Sanfu Indonesia dan Kepolisian polres Kab. Purwakarta dengan di tembuskan ke instansi yang berwenang, hal ini sesuai Pasal 140 Ayat (2) UU RI No 13/2003 tentang Ketenagakerjaan. Pada kasus mogok kerja dilakukan oleh pekerja/buruh dengan melakukan pemberitahuan terlebih dahulu yaitu dengan pihak Disnakersostrans, Management Perusahaan PT Sanfu Indonesia dan Kepolisian polres Kab. Purwakarta dengan di tembuskan ke instansi yang berwenang, hal ini sesuai dengan ketentuan Pasal 140 Ayat (2) UndangUndang Nomor 13 Tahun 2003 tentang Ketenagakerjaan. Hakim tetap memPHK antara pekerja dengan pengusaha beralasan disharmonisasi. Disharmonisasi ini terjadi karena pekerja/buruh merugikan perusahaan sehingga perusahaan melakukan PHK terhadap pekerja/buruh karena hal tersebut bukan karena adanya mogok kerja pekerja/buruh, sehingga terjadinya perselisihan pemutusan hubungan kerja karena tidak adanya kesamaan pendapat mengenai PHK yang dilakukan salah satu pihak yang mengakibatkan Putusan Hakim Nomor 67/PK/Pdt.Sus-PHI/2018 berujung pada PHK bagi pihak pekerja/buruh.

Menurut Dr. Reytman Aruan, S.H., M.Hum selaku Kasubdit Penyelesaian Perselisihan Hubungan Industrial, Kementerian Ketenagakerjaan Republik Indonesia dalam gugatan rekonvesi dalam Putusan Peninjauan Kembali di tolak, di mana gugatan rekonvensi meminta untuk pengusaha membayar hak-hak pekerja/buruh selama sebelas (11) bulan dan juga satu (1) kali uang THR. Ketentuan akan pesangon seharusnya ditulis di dalam Konvensi bukan di dalam Rekonvensi karena gugatan Pemutusan Hubungan Kerja (PHK) ada di dalam Konvensi. Gugatan Rekonvensi dari Penggugat Rekonvensi tidak mendalilkan Pemutusan Hubungan Kerja, melainkan upah yang tidak dibayar 11 bulan dan 1 bulan THR oleh Tergugat Rekonvensi, sehingga tidak tepat kalau masalah Pemutusan Hubungan Kerja (PHK) dan 
uang pesangon dituangkan didalam gugatan Rekonvensi. Tentang hal mogok kerja sebelumnya, menurut Bapak Reytman Aruan; pekerja/buruh sudah melakukan perundingan bipartit sebanyak 3 (tiga) kali tetapi perundingan tidak mencapai kata sepakat, kemudian pekerja/buruh dalam proses mediasi pada mediator dipanggil secara berturut-turut sebanyak 3 (tiga) tetapi hanya dihadiri 1 (satu) kali oleh pengusaha, sehingga dikatakan mogok kerja tersebut sebenarnya sah, karena adanya perundingan yang gagal. ${ }^{3}$

Menurut Bapak Juanda Pangaribuan, S.H, M.H. mantan hakim ad hoc, menyebutkan bahwa jika hakim berpendapat memberikan pesangon kepada pekerja/buruh, maka hal tersebut dituangkan/dibuat didalam Konvensi, bukan di dalam Rekonvensi. Hal tersebut dikarenakan yang meminta Pemutusan Hubungan Kerja adalah Perusahaan. Perusahaan meminta Pemutusan Hubungan Kerja tapi tidak memberikan pesangon hanya penggantian hak, perumahan, dan pengobatan, sehingga seharusnya hakim menyatakan bahwa terhadap (PHK) yang dilakukan pegusaha, terbukti bahwa pekerja/buruh tidak bersalah sehingga tidak beralasan apabila hanya membayar uang penggantian hak, perumahan, dan pengobatan. Majelis hakim oleh karena itu seharusnya menghukum perusahaan untuk membayar uang pesangon dua kali berdasarkan ketentuan UU No 13/2003 tentang Ketenagakerjaan dan hal tersebut dituangkan di dalam Konvensi bukan di dalam Rekonvensi. Apabila kamar/penempatan putusan itu sudah tepat, yaitu mengenai hal dua kali pesangon dimintakan dalam bagian/di dalam Konvensi, maka rekonvensi dapat ditolak.

Mengenai upah proses, upah proses itu hanya dibayar 3 bulan saja berdasarkan putusan Hakim Nomor 67PK/Pdt.Sus-PHI/2018, sedangkan permintaan gugatan pekerja/buruh tersebut kepada pengusaha untuk

\footnotetext{
${ }^{3}$ Berdasarkan hasil wawancara dengan Dr. Reytman Aruan, S.H., M.Hum pada tanggal 22 November 201 .di Kementrian Ketenagakerjaan Republik Indonesia
} 
membayar 11 bulan dan 1 kali THR. Bapak Juanda berpendapat kalau pekerja/buruh itu tidak bersalah, maka seharusnya upah proses diberikan semuanya kepada pekerja, jangan hanya 3 bulan upah proses saja. Apabila dikatakan sebaliknya bahwa pekerja/buruh itu dinyatakan bersalah maka sekalian saja upah proses tidak diberikan, karena menghitung uang upah proses 3,4,5 bulan atau di bawah ketentuan Undang-Undang lebih susah dihitungnya, jika uang upah proses tidak diberikan dapat dengan mudah memberikan alasan dengan prinsip "No Work No Pay". ${ }^{4}$

Mengenai mogok kerja yang sah merupakan hak para pekerja sehingga tidak dapat diputus hubungan kerjanya. Jika dilakukan Pemutusan Hubungan Kerjanya, maka hal tersebut dikategorikan sebagai (PHK) batal demi hukum. Batal demi hukum berdasarkan Pasal 170 UU RI Nomor 13/2003 Tentang Ketenagakerjaan yang menyebutkan bahwa PHK tidak memenuhi Pasal 151 ayat (3) dan Pasal 168 kecuali Pasal 158 ayat (1), Pasal 160 ayat (3) yang Pasal 162, Pasal 156 ayat (4), dan Pasal 169. Memang Hakim atau Pengadilan Hubungan Industrial dapat melakukan/ membuat putusan menyatakan PHK antara pengusaha dengan buruh. tetapi Putusan Hakim tersebut harus diterapkan sesuai dengan hukum. Jika memang pekerja/buruh tidak bersalah sesuai dengan kasus ini, maka hakim harus mempekerjakan kembali. Hal tersebut seperti layaknya pekerja/buruh yang di PHK menurut Pasal 153 UU No 13/2003 tentang larangan-larangan PHK. ${ }^{5}$

Pada dasarnya pekerja/buruh sudah melakukan prosedur yang tidak bertentangan dengan KEPMEN Nomor 232/2003 Tentang Akibat Hukum Mogok Kerja Yang Tidak Sah, yaitu mogok kerja tidak sah apabila dilakukan:

\footnotetext{
${ }^{4}$ Berdasarkan hasil wawancara dengan Juanda Pangaribuan, S.H, M.H. pada tanggal 4 Desember 2019 di rumah yang berada di daerah Serpong.

${ }^{5}$ Berdasarkan hasil wawancara dengan Juanda Pangaribuan, S.H, M.H. pada tanggal4 Desember 2019 di rumah yang berada di daerah Serpong.
} 
a. Bukan karena gagalnya perundingan;

b. Tanpa pemberitahuan kepada pengusaha

c. Dengan pemberitahuan kurang dari tujuh hari sebelum melakukan mogok;

d. Isi pemberitahuan tidak sesuai dengan ketentuan Pasal 140 Ayat (2) huruf a, b, c, dan d Undang-Undang Ketenagakerjaan Nomor 13 Tahun 2003.

Pekerja tersebut sebelumnya sudah melakukan proses bipartit sebanyak 3 kali, namun tidak menemukan titik temu. Sesuai dengan Pasal 3 KEPMEN 232/2003 Tentang Akibat Hukum Mogok Kerja Yang Tidak Sah, bahwa sebenarnya sudah terdapat unsur adanya gagal perundingan sehingga mogok kerja tersebut adalah sah, dan juga juga adanya pemberitahuan kepada Dinas Ketenagakerjaan, dan juga sesuai dengan bukti T dk/ p dRK-5 pada tanggal 17 November 2014 adanya perihal pemberitahuan aksi mogok kerja telah disampaikan dan diterima dengan baik oleh pengusaha, maka menurut penulis mogok kerja yang dilakukan pekerja adalah sah. Berdasarkan teori tentang perlindungan hukum menjelaskan bahwa pekerja/buruh seharusnya mendapat Perlindungan Hukum. Jika para pekerja/buruh tersebut mendapatkan perlindungan hukum, maka pekerja dapat bekerja dengan baik, perlindungan tenaga kerja dimaksudkan untuk menjamin hak para pekerja dan menjamin kesempatan, supaya tidak mendapatkan perlakuan diskriminasi atas dasar apapun untuk tercapainya kesejahteraan pekerja dan keluarganya. Sangat diperlukannya perlindungan bagi tenaga kerja karena pada dasarnya kedudukan pekerja/buruh dianggap sangat lemah dibandingkan dengan majikan atau pengusaha, Secara sosiologis dan ekonomis pekerja berada dalam kedudukan lebih rendah daripada pemberi kerja sehungga tidak mempunyai posisi nilai tawar (bargaining position) yang seimbang. Sehingga pekerja harus mendapatkan perlindungan dalam hukum terutama dalam hal pekerja diputus hubungan kerjanya oleh pengusaha/majikan. Pasal 137 UU RI 
No 13/2003 Tentang Ketenagakerjaan dasarnya mogok kerja merupakan hak pekerja yang dilakukan secara sah, tertib, dan damai sebagai akibat gagalnya berunding. Apabila perundingan gagal dan tidak tercapai kesepakatan, pekerja dapat menggunakan haknya melakukan mogok kerja.

Pekerja/buruh dalam kasus ini diputus hubungan kerjanya, bukan karena melakukan Mogok Kerja Tidak Sah, namun karena adanya disharmonisasi antara hubungan pekerja dan pengusaha yang tidak dapat lagi dipertahankan, disharmonisasi ini karena pekerja yang merugikan perusahaan. Pada dasarnya pekerja sudah melakukan prosedur yang tidak bertentangan dengan Pasal 3 KEPMEN 232/2003 Tentang Akibat Hukum Mogok Kerja Kasus mogok kerja dilakukan oleh pekerja/buruh dengan melakukan pemberitahuan terlebih dahulu yaitu dengan pihak Disnakersostrans, Management Perusahaan PT Sanfu Indonesia dan Kepolisian polres Kab. Purwakarta dengan di tembuskan ke instansi yang berwenang, berdasarkan ketentuan Pasal 140 Ayat (2) UU RI Nomor 13/2003 tentang Ketenagakerjaan, sehingga karena PHK bukan atas kesalahan penggugat rekonvensi (pekerja), maka penggugat rekonvensi (tergugat) diberikan uang pesangon dua kali sesuai Pasal 156 ayat (2) UU No 13/2003 tentang Ketenagakerjaan.

\section{B. Perlindungan Hukum Bagi Tenaga Kerja yang Mengalami Pemutusan Hubungan Kerja Karena Aksi Mogok Kerja Pada PT. SANFU Indonesia}

Perlindungan hukum bagi pekerja, adalah perlindungan terhadap hakhak asasi manusia berdasarkan ketentuan hukum dari kesewenangan atau sebagai kumpulan peraturan atau kaidah yang akan dapat melindungi suatu hal dari hal lainnya, ${ }^{6}$ Aspek perlindungan terhadap pekerja meliputi dua hal mendasar, yaitu perlindungan dari kekuasaan pengusaha dan perlindungan

\footnotetext{
${ }^{6}$ Philipus M Hadjon, Perlindungan Hukum Bagi Masyarakat Indonesia, (Surabaya: Bina Ilmu, 1983), hlm. 38
} 
dari tindakan Pemerintah, ${ }^{7}$ perlindungan pekerja secara tegas diatur berdasarkan Pasal 5 dan 6 UU RI Nomor 13/2003 tentang Ketenagakerjaan Kedua kandungan pasal ini merupakan wujud perlindungan hukum bagi para tenaga kerja. ${ }^{8}$

Undang-Undang yang mengatur perlindungan tenaga kerja:

1. Pasal 27 Ayat (2) UUD 1945,

2. Pasal 28 D ayat (1) UUD 1945,

3. Pasal 28 D ayat (2) UUD 1945, "setiap orang berhak untuk bekerja serta mendapat imbalan dan perlakuan yang adil dan layak dalam hubungan kerja”.

4. Undang-undang No 13 Tahun 2003 tentang Ketenagakerjaan.

5. Undang-undang No 2 Tahun 2004 tentang Penyelesaian Perselisihan hubungan Industrial.

Perlindungan terhadap pekerja/buruh dimua dalam Undang-Undang Nomor 13 Tahun 2003, yang menyatakan bahwa:

1. Perlindungan tentang jaminan sosial tenaga kerja;

2. Perlindungan keselamatan dan kesehatan;

3. Perlindungan hukum untuk membentuk dan menjadi anggota serikat; Pekerja/ serikat buruh;

4. Perlindungan atas hak-hak dasar pekerja untuk berunding Hukum Ketenagakerjaan mengatur hubungan kerja antara Pekerja dengan pengusaha, yang berarti mengatur kepentingan pekerja dengan pengusaha. Hubungan kerja yang mengatur antara pekerja/buruh dan pengusaha pada dasarnya memuat hak dan kewajiban dari para pihak. Untuk mewujudkan hak dan kewajiban tersebut maka dalam Pasal 106 UU No 13/2003 tentang Ketenagakerjaan menyebutkan ada suatu lembaga untuk pengusaha

\footnotetext{
${ }^{7}$ Philipus M Hadjon, Perlindungan Hukum, hal. 30,

${ }^{8}$ Indonesia, Undang-Undang Nomor 13 Tahun 2003 tentang Ketenagakerjaan, Pasal 5.
} 
dan pekerja melakukan perundingan disebut lembaga bipartite. Pasal 107 Undang-Undang No. 13 tahun 2003 tentang Ketenagakerjaan mengatur mengenai hak berunding yang lain dalam sebuah lembaga yang bernama Tripartit yang berfungsi hampir sama dengan lembaga Bipartit.

Pada kasus mogok kerja yang telah diuraikan diatas berdasarkan Putusan Nomor 67PK/Pdt.Sus-PHI/2018bahwa pekerja/buruh melakukan mogok kerja sesuai dengan prosedur yang tidak bertentangan dengan dengan Pasal 3 KEPMEN Nomor 232/2003 Tentang Akibat Hukum Mogok Kerja Yang Tidak Sah. Pada kasus mogok kerja dilakukan oleh pekerja/buruh dengan melakukan pemberitahuan terlebih dahulu yaitu dengan pihak Disnakersostrans, Management Perusahaan PT Sanfu Indonesia dan Kepolisian polres Kab. Purwakarta dengan di tembuskan ke instansi yang berwenang, sesuai ketentuan Pasal 140 Ayat (2) UU RI Nomor/Tahun 2003 tentang Ketenagakerjaan, sehingga mogok kerja yang dilakukan oleh pekerja/buruh tersebut adalah sah. Pekerja/buruh mengalami pemutusan hubungan kerja tersebut haruslah mendapatkan perlindungan, oleh karena mereka diputus hubungan kerjanya bukan karena kesalahan pekerja/buruh. Hal ini dapat dilihat dari putusan tersebut bahwa hakim memutuskan memberikan dua kali pesangon kepada pekerja/buruh tersebut. Pekerja/buruh tersebut berhak atas perlindungan hukum karena terjadinya PHK bukan karena kesalahan pekerja, dimana pekerja mendapat 2 kali uang pesangon, dimana jika mereka tidak mendapatkannya mereka tidak akan mendapatkan haknya.

Menurut Dr. Reytman Aruan, S.H., M.Hum., bagi aspek perlindungan hukum bagi tenaga kerja PT. Sanfu Indonesia, menurutnya perlindungan hukum sudah tercapai karena permasalahan 
tersebut sudah masuk dalam proses pengadilan. Sudah mendapatkan putusan yang inkracht; maka perlindungan bagi pekerja/buruh sudah terpenuhi, namun berdasarkan halnya teori keadilan, keadilan itu tidak tercapai karena itu bukan merupakan kesalahan pekerja, sehingga pekerja tidak dapat di putus hubungan kerjanya dan dipekerjakan kembali. Menurut penulis, penulis sependapat dengan Dr. Reytman Aruan, S.H., M.Hum., bahwa perlindungan hukum bagi pekerja/buruh tersebut sudah tercapai, karena perselisahan/ permasalahan yang dialami oleh pekerja/buruh tersebut sudah masuk ranah pengadilan atau dengan kata lain permasalahan/perselisihan tersebut sudah masuk ke ranah hukum, oleh karena itu perlindungan pekerja/buruh tersebut sudah terlaksana dengan baik.

Berdasarkan pendapat Bapak Juanda Pangaribuan, S.H, M.H merupakan seorang praktisi hukum dalam hubungan industrial sekaligus mantan hakim ad hoc Pengadilan Hubungan Industrial, menyebutkan bahwa Pekerja/buruh yang melakukan mogok kerja sah, kedudukannya sama dengan yang dilindungi dalam Pasal 153 UU RI Nomor 13/2003 tentang Ketenagakerjaan. Pasal 153 UU RI Nomor 13/2003 tentang Ketenagakerjaan, pekerja tidak boleh diputus hubungan kerjanya, dan harus dipekerjakan kembali, karena pekerja tidak bersalah. Menurut penulis sejalan dengan pendapat Bapak Juanda Pangaribuan S.H., M.H., karena menurut penulis sudah dibuktikan adanya perundingan yang gagal sebelumnya sesuai dengan Putusan Peninjauan Kembali, sehingga dikatakan bahwa pekerja/buruh melakukan aksi mogok kerja yang sah, dengan mogok kerja yang sah berarti sudah dilindungi oleh Ketentuan Pasal 153 UU Nomor 13/2003 tentang Ketenagakerjaan. Dimana bukan oleh kesalahan pekerja, menurut Pasal 153 UU RI Nomor 13/2003 tentang Ketenagakerjaan, 
pekerja/buruh tersebut tidak boleh diputus hubungan kerjanya dan juga harus dipekerjakan kembali.

Menurut pendapat penulis, dalam hal perlindungan hukum yang dialami oleh pekerja/buruh tersebut dalam kasus Putusan Nomor 67PK/Pdt.Sus-PHI/2018. Sudah tercapai, karena hakim menyatakan telah diputus hubungan kerjanya dan dengan pemberian uang pesangon sebanyak dua kali. PHK terjadi bukan karena adanya mogok kerja, namun karena adanya alasan disharmonis, yaitu pekerja telah melakukan hal yang merugikan perusahaan. Hal tersebut dikarenakan apabila pekerja/buruh tersebut tidak dilakukan pemutusan hubungan kerja, mereka tidak akan mendapatkan haknya sebagai pekerja. Pasal 151 Ayat (1) UU 13/2003 tentang menyebutkan pengusaha, pekerja/buruh, serikat pekerja/serikat buruh, dan pemerintah, dengan segala upaya harus mengusahakan agar jangan terjadi pemutusan hubungan kerja.

\section{III.PENUTUP}

\section{A. Kesimpulan}

1. Mengenai Putusan Hakim Terhadap PHK dengan Alasan Mogok Kerja Sah pada Putusan Peninjauan Kembali Nomor 67/PK/Pdt.Sus-PHI/2018, sudah sesuai dengan ketentuan UU RI No 13/2003 Tentang Ketenagakerjaan; mogok kerja yang dilakukan oleh pekerja/buruh adalah sah, karena pekerja/buruh sudah melakukan prosedur mogok kerja yang tidak bertentangan dengan Pasal 3 KEPMEN Nomor 232 Tahun 2003 Tentang Akibat Hukum Mogok Kerja Yang Tidak Sah, hal ini sesuai pula dengan ketentuan Pasal 140 Ayat (2) Undang-Undang Nomor 13 Tahun 2003 tentang Ketenagakerjaan. PHK dalam kasus bukan disebabkan oleh alasan mogok kerja tidak sah, namun hakim dalam amar pertimbangannya mendasarkan PHK pada kasus dengan 
alasan disharmonisasi, yaitu hubungan antara pekerja dan pengusaha sudah tidak dapat dipertahankan lagi, karena pekerja telah mangkir selama 5 (lima) hari berturut-turut dengan alasan tidak sah.

2. Akibat hukum PHK pada kasus Putusan Peninjauan Kembali nomor 67PK/Pdt.Sus-PHI/2018, berakibat pekerja mendapat perlindungan hukum yang diterima oleh pekerja/buruh PT. Sanfu Indonesia pada Putusan Peninjauan Kembali Nomor 67/PK/Pdt.Sus-PHI/2018. Hakim dalam putusannya menyatakan PHK bukan karena alasan mogok kerja, tetapi karena adanya disharmonisasi, disharmonisasi ini terjadi karena pekerja yang merugikan perusahaan dengan tidak masuk kerja selama lima hari, akibatnya hubungan antara pekerja dengan pengusaha tidak dapat lagi dipertahankan. Perlindungan bagi pekerja berupa adanya pemutusan hubungan kerja dengan pengusaha di mana pekerja mendapat uang pesangon kepada pekerja sejumlah dua kali ketentuan Pasal 156 UU No. 13/2003 tentang Ketenagakerjaan. Hal tersebut dikarenakan apabila pekerja/buruh tersebut tidak mendapat putusan berupa Pemutusan PHK, mereka tidak akan mendapatkan haknya sebagai pekerja yaitu berupa uang pesangon. Pada Putusan Nomor 67/PK/Pdt.Sus.PHI/2018, pekerja sudah melakukan mogok kerja yang sah dan tidak bertentangan dengan Pasal 3 KEPMEN Nomor 232/2003 Tentang Akibat Hukum Mogok Kerja Yang Tidak Sah. Pekerja yang melakukan mogok kerja yang sah, kedudukannya dilindungi berdasarkan Pasal 153 UU RI No 13/2003 tentang Ketenagakerjaan sehingga alasan PHK kasus ini bukan karena pekerja/buruh melakukan mogok kerja, namun karena pekerja/buruh telah melakukan kesalahan merugikan perusahaan yaitu tidak masuk kerja secara berturut-turut selama 5 lima hari. Oleh karena mogok kerja dilakukan secara sah dan bukan karena kesalahan pekerja, menurut Pasal 153 UU No 13/2003 tentang ketenagakerjaan disebutkan pekerja harus bekerja kembali. 
Hakim dalam Putusannya tidak mendasarkan PHK dengan alasan pekerja melakukan mogok kerja tidak sah, oleh karenanya hakim mendasarkan PHK nya atas pelanggaran ringan yang dilakukan oleh pekerja yaitu tidak masuk kerja 5 hari berturut-turut tanpa alasan yang sah dan oleh karenanya berakibat hukum pekerja/buruh PT San Fu Indonesia mendapatkan pesangon.

\section{B. Saran}

1 Ketentuan mengenai prosedur penyelesaian perselisihan berkaitan dengan mogok kerja seharusnya pada nantinya diatur di dalam revisi undang-undang tentang proses penyelesaian perselisihan hubungan industrial yaitu Revisi UU No 2/2004 tentang Penyelesaian Perselisihan Hubungan Industrial, agar bagi para pihak dan hakim dapat menjadikan acuan dalam menyelesaikan perselisihan hubungan industrial akibat mogok kerja

\section{Daftar Pustaka}

\section{A. Buku}

Hadjon, Philipus M. Perlindungan Hukum Bagi Masyarakat Indonesia, (Surabaya: Bina Ilmu,1983).

Suhartoyo. "Perlindungan Hukum Bagi Buruh Dalam Sistem Hukum Ketenagakerjaan Nasional", dalam Adminitrative Law \& Governance Journal. Volume 2 Issue 2, June. (Semarang: Fakultas Diponegoro, 2019) Soekanto, Soerjono. Pengantar Penelitian Hukum. (Jakarta: UI Press, 1981)

\section{B. Undang-Undang}

Indonesia. Undang-Undang Nomor 13 Tahun 2003 tentang Ketenagakerjaan. 


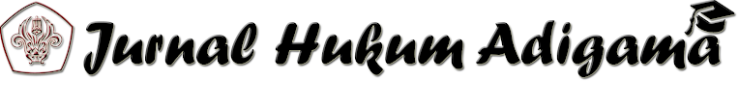

Volume 2 Nomor 2, Desember 2019

E-ISSN : 2655-7347

Indonesia. Keputusan Menteri Tenaga Kerja dan Transmigrasi Nomor 232

Tahun 2003 tentang Akibat Mogok Kerja yang Tidak Sah.

\section{Wawancara}

Berdasarkan hasil wawancara dengan Dr. Reytman Aruan, S.H., M.Hum. pada tanggal 22 November 2019 di Kementerian Ketenagakerjaan Republik Indonesia

Berdasarkan hasil wawancara dengan Juanda Pangaribuan, S.H, M.H. pada tanggal 4 Desember 2019 di rumah yang berada di daerah Serpong. 